\title{
OKOLJSKI VPLIVI PLANINSKIH KOČ V VISOKOGORJU KAMNIŠKO-SAVINJSKIH ALP
}

\author{
Nejc Bobovnik, univ. dipl. geogr. \\ Morska cesta 139, SI-23I 3 Fram \\ e-mail: bobovnik.nejc@gmail.com
}

Izvirni znanstveni članek

COBISS 1.01

DOI: $10.4312 /$ dela.41.6.117-128

\section{Izvleček}

Planinske koče so v neposeljenem gorskem svetu skoraj edini lokalni vir onesnaževanja. V raziskavi smo opredelili štiri okoljske vplive planinskih koč: oskrbovanje in ravnanje z odpadki, ogrevanje in pridobivanje električne energije, oskrba z vodo in ravnanje z odpadnimi vodami ter število in obnašanje obiskovalcev. S pomočjo ankete smo ocenili okoljske vplive izbranih planinskih koč. Najbolj problematična sta velika količina odpadkov in porabljene vode, kot dobro lahko označimo oskrbovanje, kot zelo dobro ogrevanje koč in pridobivanje električne energije.

Ključne besede: varstvo okolja, planinstvo, planinske koče, Kamniško-Savinjske Alpe, Slovenija

\section{ENVIRONMENTAL IMPACTS OF MOUNTAIN HUTS IN THE HIGH MOUNTAIN RANGE OF KAMNIK-SAVINJA ALPS}

\begin{abstract}
Mountain huts represent almost the only local source of pollution in mountain areas. We have defined four problem areas of environmental impacts of mountain huts: the supply and waste management, heating and electricity production, water supply and wastewater treatment and finally the number and behaviour of the visitors. We have evaluated environmental impacts of nine mountain huts with a questionnaire. The most problematic are the high production of waste and the quantity of water use. On the positive side is the supply of mountain huts and very positive the heat production and electricity supply.
\end{abstract}

Key words: environmental protection, mountaineering, mountain huts, Kamnik-Savinja Alps, Slovenia 


\section{UVOD}

Slovenija je z gorami in planinstvom močno povezana. Ne nazadnje je alpskega sveta $\mathrm{V}$ Sloveniji kar dobrih 42 \%, v njem pa živi skoraj polovica prebivalstva države (Slovenija ..., 1998). Posledično je tudi obisk gorskega sveta velik. Po podatkih Planinske zveze Slovenije (PZS) v hribe redno zahaja kar 315.000 Slovencev, letno pa slovenske gore obišče več kot 1,4 milijona obiskovalcev (Mihelič, 2013).

Tako veliko število obiskovalcev povzroča negativne vplive na gorsko okolje. Pri tem planinske koče delujejo kot nekakšne 'vroče točke' onesnaževanja. V njih se namreč zgoščuje obisk, hkrati pa s storitvami povzročajo okoljske vplive v okolju, kjer drugih lokalnih onesnaževalcev praktično ni.

Problema se je razmeroma zgodaj zavedla tudi Planinska zveza Slovenije, ki je leta 1991 organizirala prvi posvet o tej problematiki. Odtlej se je z različnimi projekti in akcijami naredilo veliko pozitivnega, kljub temu pa veliko problemov ostaja.

Tudi strokovni, predvsem geografski krogi so zaznali problem okoljskih vplivov planinskih koč. Rezultat tega je kar nekaj raziskav, ki so se ukvarjale s to tematiko. Nekatere so obravnavale širšo tematiko (Majerič, 2002; Bobovnik, 2012), druge so se osredotočile na določene probleme (Erhartič, 2004; Jensterle, 2013a, 2013b; Udrih, 2013). Že samo zanimanje za omenjeno tematiko potrjuje potrebo po tovrstnih raziskavah.

\section{METODE DELA}

Preučevanja okoljskih vplivov planinskih koč smo se lotili na območju KamniškoSavinjskih Alp. Kljub zelo podobnim značilnostim so bile slednje pri dosedanjih raziskavah močno zapostavljene v primerjavi z Julijskimi Alpami oziroma Triglavskim narodnim parkom. V Kamniško-Savinjskih Alpah je po seznamu Planinske zveze Slovenije (PZS) 36 planinskih koč (Seznam ..., 2013). V prvi fazi izbora koč smo jih izločili sedem, ki glede na geografske regionalizacije ne sodijo v Kamniško-Savinjske Alpe. Izločili smo tudi štiri bivake, ki jih zaradi zanemarljivih okoljskih vplivov nismo obravnavali. Od preostalih 25 planinskih postojank smo želeli izločiti tiste, ki se ne nahajajo v visokogorju. Definicije visokogorja se med seboj precej razlikujejo, za potrebe izbora planinskih koč smo se odločili za kategorizacijo planinskih koč pri Gospodarski komisiji Planinske zveze Slovenije (Kaj je planinska koča, 2013). Slednja razvršča koče na podlagi lokacije (visokogorje ali sredogorje) in dostopnosti (čas hoje do koče). Koče, do katerih traja dostop več kot uro ter ležijo v visokogorju, so uvrščene v prvo kategorijo. Na ta način smo prišli do 9 koč (slika 1), ki ustrezajo vsem naštetim merilom.

Okoljske vplive izbranih planinskih koč smo poskušali ugotoviti s pomočjo anketnega vprašalnika za planinska društva in oskrbnike planinskih koč. Na žalost je bil predvsem odziv planinskih društev zelo slab in ni omogočal dodatnih primerjav stališč enih in drugih do obravnavane problematike. Anketiranje oskrbnikov na terenu je potekalo med 19. julijem in 1. avgustom 2012. Kljub vsem težavam smo pridobili zadovoljivo dobre podatke, ki nam omogočajo vpogled v okoljske vplive planinskih koč. Vprašalnik je obsegal 22 vprašanj, ki so bila razdeljena v pet tematskih kategorij: oskrbovanje in 
ravnanje z odpadki, ogrevanje in pridobivanje električne energije, oskrba z vodo in ravnanje z odpadnimi vodami, število in obnašanje obiskovalcev ter načrti in problemi. Večina vprašanj je bila zaprtega tipa, kar je omogočilo lažjo analizo in primerjavo, nekatera, predvsem o načrtih in problemih, pa so bila odprtega tipa.

\section{Slika 1: Lokacije preučevanih planinskih koč}

Figure 1: The locations of the studied mountain huts

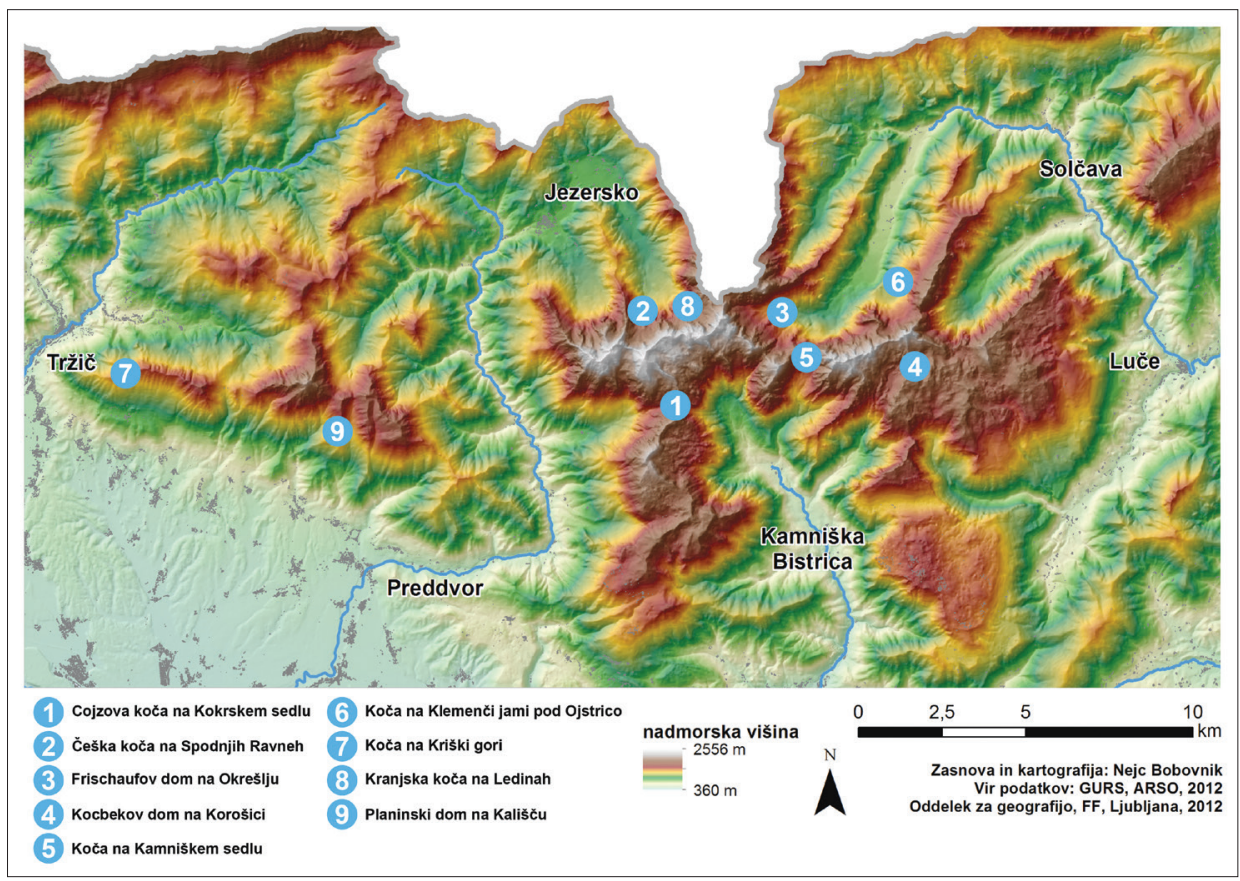

Okoljske vplive smo ocenjevali na podlagi odgovorov iz vprašalnika. Skupna ocena okoljskih vplivov je bila sestavljena iz treh ocen za posamezna problemska področja, ki so opredeljena v nadaljevanju. Za ocenjevanje smo uporabili šest kazalcev in pet podkazalcev. Vrednotenje kazalcev je potekalo številsko od 1 (zelo veliki okoljski vplivi) do 5 (zelo majhni okoljski vplivi).

\section{VPLIV PLANINSKIH KOČ NA OKOLJE}

Od pojava planinskih koč do današnjih dni so se te precej spremenile. Od začetnih skromnih zavetišč je šel razvoj v smeri večanja udobja, v oblikovanje 'gorskih hotelov'. S tem so se povečevali tudi njihovi vplivi na okolje. Okoljske vplive planinskih koč bi sicer lahko opredelili kot seštevek okoljskih vplivov planinstva, oziroma turizma kot takega, ter okoljskih vplivov nastanitvenih objektov. Temu moramo dodati še pokrajinsko občutljivost gorskega sveta, ki negativne okoljske vplive še potencira. Poleg neposrednih 
okoljskih vplivov planinskih koč, kot so na primer izpusti odpadnih voda ter hrup in svetlobno onesnaženje, moramo upoštevati še posredne vplive. To so predvsem okoljski vplivi, povezani s hojo po planinskih poteh (povečana potna erozija, motenje divjih prostoživečih živali, pritiski na naravno rastje). Planinske koče namreč povečujejo obisk na planinskih poteh, ki vodijo do teh postojank, ter na poteh naprej proti vrhovom.

V primerjavi z nastanitvenimi objekti v dolini (hoteli, gostišča, penzioni, moteli ...) so obremenitve planinskih koč precej manjše (Cigale, 2007), vendar le po obsegu, ne pa tudi po pomenu. Planinske koče se namreč nahajajo v večinoma neposeljenem svetu, kjer so edini lokalni onesnaževalec (vsaj, kar se tiče objektov). Večji vpliv na okolje stopnjujeta še odsotnost primerne infrastrukture ter večja občutljivost naravnega okolja (Cigale, 2009).

V nadaljevanju opredeljujemo štiri problemske sklope, povezane s planinskimi kočami:

- oskrbovanje in ravnanje z odpadki;

- ogrevanje in pridobivanje električne energije;

- oskrba z vodo in ravnanje z odpadnimi vodami;

- število in obnašanje obiskovalcev.

Planinske koče potrebujejo za obratovanje precej dobrin (drva in druge energente, živila, pijače), ki jih je treba zagotoviti iz doline. Oskrbovanje planinskih koč je najbolj problematično ravno v visokogorju, saj do njih ni dovoznih cest, ki bi omogočale oskrbovanje $\mathrm{z}$ avtomobilom ali traktorjem. Potrebno je uporabiti druge načine, od helikopterja in tovorne žičnice do oskrbe s konji ali peš. Za najboljše od naštetih so se izkazale tovorne žičnice, ki so ugodne tako z ekonomskega kot tudi okoljskega vidika, ter oskrbovanje s konji, ki pa je dražje. Najmanj primeren način je oskrbovanje s helikopterji (Udrih, 2013). Hkrati z oskrbovanjem govorimo tudi o odvozu odpadkov v dolino, saj moramo vse, kar na kočo pripeljemo, tako ali drugače spraviti nazaj v dolino. Včasih temu na planinskih kočah ni bilo tako, saj so marsikje imeli (ne)urejene deponije pred kočami, veliko odpadkov pa so tudi sežigali. Omeniti moramo tudi preveliko razkošje in ponudbo v planinskih kočah, ki ima za posledico (pre)velike količine odpadkov.

Visokogorske planinske postojanke uporabljajo za ogrevanje večinoma drva, v manjšem deležu pa tudi plin ali celo kurilno olje, ki predstavlja okoljsko nesprejemljiv način ogrevanja. Za pridobivanje električne energije v veliki meri uporabljajo obnovljive vire energije, tako fotovoltaične sisteme kot vetrne generatorje. Vendar pa naravni potenciali za pridobivanje električne energije niso izkoriščeni dovolj, na kar kažejo podatki iz Triglavskega narodnega parka, ki bi jih lahko prenesli tudi na Kamniško-Savinjske Alpe (Jensterle, 2013). Iz navedenega dela je razvidno, da še vedno precej uporabljajo tudi dizelske ali bencinske agregate, katerih uporabo bi bilo potrebno čim bolj omejiti.

Odpadne vode iz planinskih postojank so bržkone njihova največja težava in grožnja za okolje. Razloga sta predvsem velika občutljivost gorskega okolja, ki je tudi vir pitne vode za nižje ležeči svet, in prostorska razpršenost (potencialnih) virov onesnaževanja (Cigale, 2007). Visokogorske planinske koče dobivajo vodo iz bližnjih izvirov ali z zbiranjem kapnice. Glavni viri odpadne vode so sanitarije, kuhinje in pralnice. Problem pranja posteljnine je delno rešen s pranjem posteljnine v dolini ter uvedbo osebne posteljnine, ki jo obiskovalci prinesejo s sabo. Večji problem predstavljajo sanitarije, kjer se porablja 
zelo veliko pitne vode. Porabo vode bi lahko zmanjšali tudi v kuhinjah z zmanjšanjem raznolikosti ponudbe hrane. Končni proces pri rabi vode je seveda čiščenje odpadnih voda, za kar obstajajo različni načini - od različnih tipov greznic do okoljsko bolj sprejemljivih bioloških in rastlinskih čistilnih naprav (Duhovnik, 2000).

Okoljski vplivi planinskih koč so v veliki meri odvisni tudi od obiskovalcev. Na eni strani je to številčnost obiskovalcev, ki posledično povečuje okoljske vplive, na drugi strani njihova okoljska ozaveščenost. Slednje namreč neposredno vpliva na ravnanje obiskovalcev in njihove zahteve, ki so marsikdaj take kot $v$ dolini. V nadaljevanju števila obiskovalcev kot gonilne sile pritiskov ne bomo obravnavali, z izjemo vključenosti podatkov v izračun porabe vode.

\section{OCENA OKOLJSKIHVPLIVOV IZBRANIH PLANINSKIH KOČ}

Okoljske vplive izbranih planinskih koč smo analizirali s pomočjo anketnega vprašalnika. V prvi fazi dela smo rezultate anketiranja analizirali samo opisno, v drugem pa smo izdelali nabor kazalcev, s katerimi smo vrednotili okoljske vplive planinskih koč. Uporaba kazalcev je uveljavljen postopek, ki se uporablja za določanje okoljskih pritiskov (Vintar Mally, 2006; Vovk Korže, 2008). Kazalci pa imajo poleg prednosti tudi omejitve, s čimer smo se srečali tudi v naši raziskavi. Med pomembnejše prednosti zagotovo sodijo poenostavljanje in zgoščanje bistvenih informacij, kot tudi uporabnost kazalcev za spremljanje okoljskih vplivov na obravnavanem področju (Vintar Mally, 2006). Z uporabljenimi kazalci smo posegli na okoljsko polje sonaravnosti, oziroma med pritiske z vidika DPSIR modela. Naš nabor kazalcev sestoji iz šestih kazalcev in petih podkazalcev, iz katerih smo izračunali ocene za vsako izmed treh problemskih področij. Poudariti je potrebno, da gre za kvalitativne kazalce, saj izvirajo iz rezultatov anket.

Preglednica 1: Kazalci in podkazalci za vrednotenje okoljskih vplivov planinskih postojank po problemskih področjih

Table 1. Indicators and sub-indicators used for the evaluation of environmental impacts of mountain huts

\begin{tabular}{|l|l|l|}
\hline Problemsko področje & Kazalec & Podkazalec \\
\hline \multirow{2}{*}{$\begin{array}{l}\text { Oskrbovanje in ravnanje z } \\
\text { odpadki }\end{array}$} & Način oskrbovanja & - \\
\cline { 2 - 3 } & Ravnanje z odpadki & Ločevanje odpadkov \\
\cline { 3 - 3 } & & Kompostiranje \\
\cline { 3 - 3 } & & Odvoz/odlaganje odpadkov \\
\hline \multirow{2}{*}{$\begin{array}{l}\text { Ogrevanje in pridobivanje } \\
\text { električne energije }\end{array}$} & Ogrevanje koče & - \\
\cline { 2 - 3 } $\begin{array}{l}\text { Oskrba z vodo in ravnanje z } \\
\text { odpadnimi vodami }\end{array}$ & Pridobivanje električne energije & - \\
\cline { 2 - 3 } & Način čiščenja odpadnih voda & - \\
\hline & Poraba vode & $\begin{array}{l}\text { Število dnevnih obiskovalcev in } \\
\text { nočitev }\end{array}$ \\
\cline { 3 - 3 } & & Ukrepi za varčevanje z vodo \\
\hline
\end{tabular}

Skupna ocena problemskih področij je izračunana kot povprečje pripadajočih kazalcev. Vsak kazalec tako prispeva šestino k skupni oceni okoljskih vplivov, podkazalci pa 
sorazmerno manjši delež, odvisen od njihovega števila. V takšnem primeru se vrednost kazalca izračuna kot povprečje podkazalcev. Podatki za vse kazalce in podkazalce, z izjemo porabe vode, izhajajo neposredno iz rezultatov anketnega vprašalnika. Omenjeni kazalec je sicer prav tako izračunan iz podkazalcev iz anketnega vprašalnika, vendar po posebnem obrazcu, ki ga povzemamo po Baragi (2002, str. 32) in Brezigarju (1997, str. 3; cv: Erhartič, 2004, str. 56-57). V obrazcu je uporabljena povprečna poraba vode po kategorijah (osebje, nočitev, dnevni obiskovalec) v litrih na dan. Po tej študiji porabi največ vode osebje (vsak član 50-100 1/dan), manj obiskovalec, ki v koči prenoči (25-60 1/dan), najmanj pa dnevni obiskovalec $(5-15 \mathrm{l} / \mathrm{dan})$. Vrednost znotraj razpona porabe vode, ki jo uporabimo za izračun, je odvisna od ukrepov za varčevanje z vodo na kočah. Pri tem smo upoštevali predvsem vrsto stranišča, sicer pa lahko za tako oceno uporabljamo še prisotnost varčnih pip, možnost tuširanja ter ali na postojanki perejo posteljnino. Če so navedeni ukrepi za varčevanje vode prisotni, smo za izračun kazalca uporabili najnižjo vrednost razpona, če ukrepov ni, pa najvišjo. Podobno metodo je uporabil tudi Erhartič (2004, str. 57). Na opisani način smo iz podatkov o nočitvah in dnevnih obiskovalcih izračunali letno porabo vode oziroma letno obremenjevanje okolja z odpadnimi vodami.

Kazalce in podkazalce smo ovrednotili s številskimi ocenami od 1 do 5 , pri čemer je ocena 1 predstavljala zelo velike, ocena 5 pa zelo majhne okoljske vplive. V preglednici 2 so prikazani rezultati vrednotenja uporabljenih kazalcev in podkazalcev.

Preglednica 2: Pregled možnih ocen pri posameznem kazalcu ali podkazalcu Table 2: Overview of the estimates for each indicator and sub-indicators

\begin{tabular}{|l|l|l|l|l|l|}
\hline \multicolumn{1}{|c|}{ Okoljski vplivi } & Zelo velik (1) & Velik (2) & Srednje velik (3) & Majhen (4) & $\begin{array}{l}\text { Zelo majhen } \\
\text { (5) }\end{array}$ \\
\hline Način oskrbovanja & Helikopter & - & $\begin{array}{l}\text { Dizelska ali } \\
\text { bencinska žičnica }\end{array}$ & $\begin{array}{l}\text { Električna } \\
\text { žičnica }\end{array}$ & Nošnja s konji \\
\hline Ločevanje odpadkov & - & ne & - & da & - \\
\hline Kompostiranje & - & ne & - & da & - \\
\hline $\begin{array}{l}\text { Odvoz/odlaganje } \\
\text { odpadkov }\end{array}$ & $\begin{array}{l}\text { Urejena ali } \\
\text { neurejena } \\
\text { deponija, sežig }\end{array}$ & - & - & $\begin{array}{l}\text { Odvoz } \\
\text { odpadkov v } \\
\text { dolino }\end{array}$ & - \\
\hline Ogrevanje koče & $\begin{array}{l}\text { Kurilno olje } \\
\text { Plinska peč }\end{array}$ & - & $\begin{array}{l}\text { Električna } \\
\text { energija iz } \\
\text { omrežja }\end{array}$ & $\begin{array}{l}\text { Sončni } \\
\text { kolektorji, drva }\end{array}$ \\
\hline $\begin{array}{l}\text { Pridobivanje } \\
\text { električne energije }\end{array}$ & Agregat & - & - & $\begin{array}{l}\text { Javno } \\
\text { omrežje }\end{array}$ & $\begin{array}{l}\text { Sončne celice, } \\
\text { MHE, vetrna } \\
\text { elektrarna }\end{array}$ \\
\hline $\begin{array}{l}\text { Način čiščenja } \\
\text { odpadnih voda }\end{array}$ & $\begin{array}{l}\text { Greznica s } \\
\text { ponikanjem }\end{array}$ & $\begin{array}{l}\text { Vodotesna } \\
\text { greznica }\end{array}$ & - & $\begin{array}{l}\text { Rastlinska) } \\
\text { čistilna naprava }\end{array}$ \\
\hline Poraba vode & nad $400 \mathrm{~m}^{3}$ & $301-400 \mathrm{~m}^{3}$ & $201-300 \mathrm{~m}^{3}$ & 101-200 $\mathrm{m}^{3}$ & pod 100 $\mathrm{m}^{3}$ \\
\hline
\end{tabular}

Opomba: znak - pomeni, da nobenega od obstoječih načinov ne uvrščamo $v$ določen rang okoljskih vplivov. 
Z vrednotenjem kazalcev in podkazalcev iz preglednice 2 smo izbranim planinskim kočam pripisali ustrezne ocene, ki so prikazane v preglednici 3. Kot najbolj problematično se je izkazalo kompostiranje, saj na večini koč biološke odpadke odlagajo v bližini koče. Med vsemi kazalci ima način oskrbovanja najnižjo povprečno oceno. Na tem področju bi že z majhnimi vlaganji dosegli pomembne izboljšave. Na negativni strani je še poraba vode, ki je na nekaterih kočah prevelika. Čeprav se večina koč vsaj občasno srečuje s pomanjkanjem vode, pa je bilo narejenega zelo malo za varčevanje z vodo. Kot najbolj pozitivno ocenjujemo ogrevanje koč in dejstvo, da vse koče odpadke odvažajo v dolino.

Preglednica 3: Ocene okoljskih vplivov za posamezne koče

Table 3: Evaluation of the environmental impact for individual mountain huts

\begin{tabular}{|c|c|c|c|c|c|c|c|c|c|}
\hline Problemsko področje & Oskrbo & vanje in & ravna & nje $z$ od & adki & $\begin{array}{l}\text { Ogreva } \\
\text { pridobi } \\
\text { električ } \\
\text { energije }\end{array}$ & $\begin{array}{l}\text { nje in } \\
\text { vanje } \\
\text { ne }\end{array}$ & $\begin{array}{l}\text { Oskrba z } \\
\text { in ravnan } \\
\text { z odpadn } \\
\text { vodami }\end{array}$ & $\begin{array}{l}\text { vodo } \\
\text { mi } \\
\text { mi }\end{array}$ \\
\hline Kazalec & 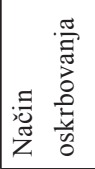 & Ravna & ije z o & dpadki & & 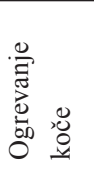 & 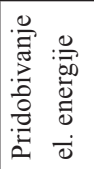 & 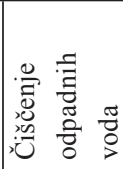 & $\begin{array}{l}0 \\
0 \\
0 \\
\pi \\
0 \\
0 \\
0 \\
0 \\
0\end{array}$ \\
\hline Planinska koča & & 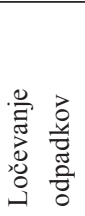 & 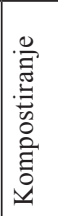 & 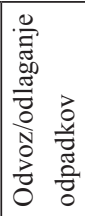 & 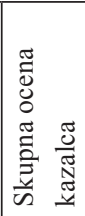 & & & & \\
\hline $\begin{array}{l}\text { Cojzova koča na Kokrskem } \\
\text { sedlu }\end{array}$ & 3 & 4 & 4 & 4 & 4 & 5 & $5(5 / 5)$ & 5 & 4 \\
\hline $\begin{array}{l}\text { Češka koča na Spodnjih } \\
\text { Ravneh }\end{array}$ & 3 & 4 & 4 & 4 & 4 & 5 & 1 & 5 & 3 \\
\hline $\begin{array}{l}\text { Frischaufov dom na } \\
\text { Okrešlju }\end{array}$ & 4 & 2 & 4 & 4 & 3,3 & $4(5 / 2)$ & 4 & 5 & 1 \\
\hline Kocbekov dom na Korošici & $2(1 / 5)$ & 2 & 2 & 4 & 2,7 & $5(5 / 5)$ & $3(5 / 1)$ & 2 & 3 \\
\hline Koča na Kamniškem sedlu & 3 & 4 & 2 & 4 & 3,3 & 5 & $3(5 / 1)$ & 5 & 3 \\
\hline $\begin{array}{l}\text { Koča na Klemenči jami pod } \\
\text { Ojstrico }\end{array}$ & 3 & 4 & 2 & 4 & 3,3 & 5 & 4 & 1 & 5 \\
\hline Koča na Kriški gori & 3 & 4 & 2 & 4 & 3,3 & 5 & 4 & 1 & 3 \\
\hline Kranjska koča na Ledinah & 3 & 4 & 4 & 4 & 4 & 5 & 5 & 5 & 4 \\
\hline Planinski dom na Kališču & 3 & 4 & 2 & 4 & 3,3 & $5(5 / 5)$ & 5 & 5 & 4 \\
\hline Povprečna ocena kazalca & 3,0 & 3,6 & 2,9 & 4,0 & 3,5 & 4,9 & 3,8 & 3,8 & 3,3 \\
\hline
\end{tabular}

Opomba: Če obstajata različna načina ravnanja, sta v oklepaju prikazani vrednosti za oba načina. Končna ocena ustreza povprečju ocen obeh načinov. 
Pri interpretaciji rezultatov je potrebno biti previden, saj višja ocena pomeni manjše okoljske vplive. Prav tako je pomembno, da ne vrednotimo samo skupne ocene, temveč tudi ocene po posameznih problemskih področjih. Na ta način lahko hitro ugotovimo, na katerem področju prihaja do največjih pomanjkljivosti in hkrati groženj za okolje. Še posebej pozorni moramo biti na zelo nizke ocene (1 ali 2) in tem problemom nameniti posebno pozornost. Rezultati vrednotenja so prikazani v preglednici 4.

Pri načinu oskrbovanja in ravnanju z odpadki nam razmeroma nizka povprečna ocena nakazuje srednje velike okoljske vplive. Razlogi so predvsem v veliki količini odpadkov, saj je bilo za zmanjšanje njihove količine narejenega premalo. $Z$ vidika oskrbovanja je najbolj problematično oskrbovanje Kocbekovega doma na Korošici s helikopterjem, smiselno bi bilo tudi zamenjati dizelske in bencinske žičnice z električnimi.

Okoljski vplivi ogrevanja koč in pridobivanja električne energije so zelo majhni, saj gre $\mathrm{v}$ veliki večini primerov za ogrevanje na drva ter pridobivanje električne energije $\mathrm{s}$ pomočjo sončnih celic in vetrnih generatorjev. Kljub temu ponekod še prihaja do pretirane uporabe dizelskih in bencinskih agregatov, kar je najbolj problematično na Češki koči.

Čiščenje odpadnih voda je zelo dobro rešeno na šestih obravnavanih kočah, zelo problematično pa je na preostalih treh. Te koče še vedno uporabljajo greznice, ki predstavljajo (zelo) velike okoljske obremenitve. Poraba vode je povezana s številom obiskovalcev, pri čemer je pomembno tudi, ali gre za dnevne obiskovalce ali nočitve, in z varčevalnimi ukrepi v koči. Smiselno bi se bilo osredotočiti predvsem na slednje, saj na število obiskovalcev ne moremo, oziroma ne želimo vplivati. Varčevanje z vodo je slabo oziroma neučinkovito prav na vseh kočah, z izjemo Koče na Kriški gori. Ta si je oceno dobro prislužila zaradi nameščenih suhih stranišč. Pri varčevanju z vodo bi že z razmeroma majhnimi ukrepi lahko precej zmanjšali porabo vode in s tem tudi količino odpadnih voda.

Preglednica 4: Ocena skupnih okoljskih vplivov preučevanih planinskih koč Table 4: Evaluation of overall environmental impacts of the studied mountain huts

\begin{tabular}{|l|c|c|c|c|}
\hline Planinska koča & $\begin{array}{l}\text { Oskrbovanje } \\
\text { in ravnanje z } \\
\text { odpadki }\end{array}$ & $\begin{array}{l}\text { Ogrevanje koče } \\
\text { in pridobivanje } \\
\text { električne energije }\end{array}$ & $\begin{array}{l}\text { Poraba vode in } \\
\text { način čiščenja } \\
\text { odpadnih voda }\end{array}$ & $\begin{array}{l}\text { Skupna ocena } \\
\text { okoljskih } \\
\text { vplivov }\end{array}$ \\
\hline Cojzova koča na Kokrskem sedlu & 3,5 & 5 & 4,5 & $\mathbf{4 , 3}$ \\
\hline Kranjska koča na Ledinah & 3,5 & 5 & 4,5 & $\mathbf{4 , 3}$ \\
\hline Planinski dom na Kališču & 3,2 & 5 & 4,5 & $\mathbf{4 , 2}$ \\
\hline Koča na Kamniškem sedlu & 3,2 & 4 & 4 & $\mathbf{3 , 7}$ \\
\hline Frischaufov dom na Okrešlju & 3,7 & 4 & 3 & $\mathbf{3 , 6}$ \\
\hline $\begin{array}{l}\text { Koča na Klemenči jami pod } \\
\text { Ojstrico }\end{array}$ & 3,2 & 4,5 & 3 & $\mathbf{3 , 6}$ \\
\hline Čěka koča na Spodnjih Ravneh & 3,5 & 3 & 2 & $\mathbf{3 , 5}$ \\
\hline Koča na Kriški gori & 3,2 & 4,5 & $\mathbf{3 , 2}$ \\
\hline Kocbekov dom na Korošici & 2,4 & 4 & $\mathbf{3 , 0}$ \\
\hline $\begin{array}{l}\text { Povprečna ocena po } \\
\text { problemskih področjih }\end{array}$ & $\mathbf{3 , 3}$ & $\mathbf{4 , 3}$ & $\mathbf{3 , 6}$ & $\mathbf{3 , 7}$ \\
\hline
\end{tabular}


Skupna ocena okoljskih vplivov nam kaže precej velike razlike med okoljskimi vplivi preučevanih planinskih postojank. Kot majhne do zelo majhne bi lahko ocenili okoljske vplive Cojzove koče, Kranjske koče ter Doma na Kališču. Srednje veliki so okoljski vplivi Kocbekovega doma in Koče na Kriški gori. Preostale štiri koče se po ocenah vseh treh kazalcev uvrščajo v kategorijo srednje velikih ali majhnih okoljskih vplivov. Vzrokov za različne ocene okoljskih vplivov je več, od okoljske ozaveščenosti planinskih društev in razpoložljivih sredstev do lege koče ali sodelovanja v čezmejnih projektih.

\section{SKLEP}

Poznavanje problema, v našem primeru okoljskih vplivov planinskih koč, je ključnega pomena za njegovo reševanje. $Z$ raziskavo smo želeli predstaviti in opozoriti na problem okoljskih vplivov planinskih koč in hkrati poiskati metode, ki omogočajo nadaljnje analize in medsebojne primerjave. Uporabljene metode in tehnike omogočajo hitro in enostavno celovito oceno okoljskih vplivov planinskih koč ter njihovo medsebojno primerjavo. Predstavljene metode je možno uporabljati tudi na drugih področjih, kot tudi v različnih časovnih obdobjih (če razpolagamo s podatki), in kot take lahko učinkovito služijo opozarjanju na probleme. Za načrtovanje sanacije planinskih koč pa jih moramo nadgraditi s podrobnejšimi raziskavami.

Za izbranih devet planinskih koč v visokogorju Kamniško-Savinjskih Alp smo ugotovili, da so njihovi okoljski vplivi od srednje veliki do zelo majhni. V splošnem se kot najbolj problematična kažeta veliki količini proizvedenih odpadkov in porabljene vode $\mathrm{v}$ povezavi s slabim varčevanjem z vodo. Pomembna je tudi odsotnost čistilnih naprav na treh kočah. Kot dobre lahko označimo načine oskrbovanja, kot zelo dobro pa ogrevanje koč in pridobivanje električne energije.

Želimo si lahko, da bi se okoljski vplivi planinskih koč v prihodnje še zmanjšali in bi planinske koče predstavljale tudi pozitiven zgled. Hkrati se moramo zavedati, da pomenijo potrebne investicije velik finančni zalogaj za prostovoljska planinska društva, ki ne razpolagajo z znatnejšimi finančnimi sredstvi. Zato bi morala k okoljski sanaciji aktivneje pristopiti tudi PZS ter k sodelovanju pritegniti zasebne investitorje in državo, ki bi take projekte podprla. Ne nazadnje pa se mora še precej spremeniti miselnost obiskovalcev planinskih postojank. Koče morajo spet postati zavetišča $\mathrm{v}$ pravem pomenu besede, dolinske navade in razvade pa je potrebno pustiti v dolini. Z okoljsko ozaveščenostjo obiskovalcev bo delo oskrbnikov planinskih koč zagotovo lažje.

\section{Viri in literatura}

Baraga, I., 2002. Vodnoekološka problematika odpadnih voda planinskih postojank občine Kranjska Gora (v TNP). Diplomsko delo. Ljubljana, Filozofska fakulteta, Oddelek za geografijo, 128 str.

Bobovnik, N., 2012. Okoljski vplivi planinskih koč na primeru visokogorja KamniškoSavinjskih Alp. Zaključna seminarska naloga. Ljubljana, Filozofska fakulteta, Oddelek za geografijo, 56 str. URL: http://geo.ff.uni-lj.si/pisnadela/pdfs/zaksem_201212 nejc_bobovnik.pdf (Citirano 7. 12. 2013). 
Brezigar, B., 1997. Čiščenje odpadnih vod koče pri Triglavskih jezerih. Študija C-703. Ljubljana, Vodnogospodarski inštitut, 40 str.

Cigale, D., 2007. Vplivi turizma v slovenskem alpskem svetu na vode. Dela, 28, str. 255-271. DOI: http://dx.doi.org/10.4312/dela.28.18.255-271

Cigale, D., 2009. Vpliv nastanitvenih objektov na okolje. V: Špes, M., Ogrin, D. (ur.). Okoljski učinki prometa in turizma v Sloveniji (Zbirka GeograFF, 5). Ljubljana, Znanstvena založba Filozofske fakultete, str. 106-121. URL: http://geo.ff.uni-lj.si/ sites/default/files/geograff_5.pdf (Citirano 17. 11. 2014).

Duhovnik, J., 2000. Planinska koča in okolje. V: Duhovnik, J., Sbrizaj, D. (ur.). Planinske koče in varstvo okolja. Zbornik. Ljubljana, Planinska zveza Slovenije, str. 4-15.

Erhartič, B., 2004. Presoja uporabnosti rastlinskih čistilnih naprav pri postojankah Triglavskega narodnega parka. Diplomsko delo. Ljubljana, Filozofska fakulteta, Oddelek za geografijo, 134 str. URL: http://geo.ff.uni-lj.si/pisnadela/pdfs/dipl_200704_ bojan_erhartic.pdf (Citirano 17. 11.2014).

Jensterle, U., 2013a. Geografska analiza energetske oskrbe in potenciala za rabo sončne energije na planinskih postojankah Triglavskega narodnega parka. Diplomsko delo. Ljubljana, Filozofska fakulteta, Oddelek za geografijo, 131 str. URL: http://geo. ff.uni-lj.si/pisnadela/pdfs/dipl_201303_urban_jensterle.pdf (Citirano 17. 11. 2014).

Jensterle, U., 2013b. Energetska samozadostnost planinskih postojank v Triglavskem narodnem parku. Dela, 40, str. 215-231. DOI: 10.4312/dela.40.12.215-231

Kaj je planinska koča. URL: http://www.pzs.si/vsebina.php?pid=16 (Citirano 6. 12. 2013).

Majerič, B., 2002. Vplivi planinskih koč v Sloveniji na okolje. Diplomsko delo. Maribor, Filozofska fakulteta, Oddelek za geografijo, 127 str.

Mihelič, Z., 2013. Varneje v gore. URL: http://www.pzs.si/novice.php?pid=8459 (Citirano 13. 10. 2013).

Seznam koč, zavetišč in bivakov. Kamniške in Savinjske Alpe. PZS. URL: http://www. pzs.si/koce.php?reg=4 (Citirano 6. 12. 2013).

Slovenija - pokrajine in ljudje. 1998. Perko, D., Orožen Adamič, M. (ur.). Ljubljana, Mladinska knjiga, 735 str.

Udrih, P., 2013. Oskrbovanje planinskih koč v Triglavskem narodnem parku. Zaključna seminarska naloga. Ljubljana, Filozofska fakulteta, Oddelek za geografijo, 36 str. URL: http://geo.ff.uni-lj.si/pisnadela/pdfs/zaksem_201309_petra_udrih.pdf (Citirano 17. 11. 2014).

Vintar Mally, K., 2006. Prednosti in omejitve uporabe kazalcev sonaravnega razvoja. Dela, 26, str. 43-59. DOI: http://dx.doi.org/10.4312/dela.26.4.43-59

Vovk Korže, A. 2008 Pogled na indikatorje - kazalce za merjenje trajnostnega razvoja, Dela, 29, str. 103-118. DOI: 10.4312/dela.29.8.103-118 


\section{ENVIRONMENTAL IMPACTS OF MOUNTAIN HUTS IN THE HIGH MOUNTAIN RANGE OF KAMNIK-SAVINJA ALPS}

\section{Summary}

The Slovenian mountain ranges have a large number of visitors. According to the Alpine Association of Slovenia (Planinska zveza Slovenije), about 315.000 Slovenians visit the mountains regularly. On yearly basis the number exceeds 1,4 million visitors (Mihelič, 2013). Such a high number has a negative environmental impact on the high mountain environment. In this environment, mountain huts act like 'hot spots' of pollution. The reason is a high concentration of visitors near these mountain huts, moreover, with their actions they also cause negative environmental impacts in an area where other human activities are practically non-existing. Those environmental impacts are very poorly studied, with the exception of the Triglav National Park (Triglavski narodni park). This is especially true for a general evaluation of the environmental impacts. This paper represents the first complete analysis of the environmental impacts of huts in the high mountain range of Kamnik-Savinja Alps.

We analysed nine mountain huts in the Kamnik-Savinja Alps; they all belong with the first category of mountain huts according to criteria of Alpine Association of Slovenia (Kaj je planinska koča, 2013). This means the huts are located in the high mountains and at least an hour of walk is needed to reach them. The chosen huts are presented in Figure 1. We tried to define their environmental impacts with a questionnaire for the mountaineering clubs and hut keepers. The questionnaire included 22 questions, divided into 5 categories according to their topic. Interviews with the managers of mountain huts were held between 19 July and 1 August 2012.

After studying the literature, we defined four problem areas of environmental impacts of mountain huts: the supply of mountain huts and the waste management, heating and electricity production, water supply and the wastewater treatment and, finally, the number and behaviour of the visitors.

The first topic involves the way of the supply of mountain huts, where environmentally the most appropriate way is by horse or by cargo lift and an inappropriate way is by helicopter. Connected to the supply of mountain huts is also the transport of waste to the valley, which is the only suitable way of dealing with it but, it is of great importance to reduce the quantity of waste generated and by additional treatment. For heating and electricity production, the latter proves to be much more difficult. Electrical supply depends on electricity generators, which are still quite common in the mountain huts. Their usage has to be limited and their surroundings appropriately organised (sound insulation, prevention of fuel leak). It is necessary to gain as much energy as possible from photovoltaic systems and wind turbines. For heating, the most suitable is the wood, which is also the predominant one. Moreover, heating with solar thermal panels is also suitable. On the other hand, oil-fired furnaces are absolutely inappropriate and unacceptable in the mountain huts. Wastewater presents the most serious threat to the mountain environment; therefore, the building of wastewater treatment plants is essential. Concerning the wastewater, it is necessary to reduce the water use as much as possible, especially for toilets. They 
should be replaced with dry toilets. The washing of bedding should be prohibited and the showering of the visitors strongly limited. It is necessary to change the people's behaviour, to educate them and to try to establish a greater environmental awareness.

We analysed the environmental impacts of selected mountain huts with the questionnaire. In the first phase, we analysed the data only descriptively and in the next phase we made a set of indicators, which graded the environmental impacts of mountain huts. Six indicators and five sub-indicators were defined. On their basis we calculated three problem areas: the supply of mountain huts and the waste management, heating and electricity production, water supply and the wastewater treatment. The results show that the environmental impacts of selected mountain huts range from medium high to very low. In general, the most problematic are the large quantity of waste and high water use in combination with poor water saving. An important factor is also the absence of wastewater treatment plants in three huts. On the positive side, there are the supply of mountain huts, heating and electricity production.

The used methodology allows a swift and easy way for a comprehensive assessment of all the environmental impacts of mountain huts and a comparison between them. Moreover, this methodology could be used in other areas and in different time frames, too. As such, it can effectively highlight the key problems. However, for environmental improvement of mountain huts further and more detailed research is necessary.

(Translated by David Sever) 